\title{
SIM Kemiskinan Sebagai Dasar Informasi Geografis Untuk Pemetaan Prioritas Pengentasan Kemiskinan di Kabupaten Banjarnegara
}

\author{
A. Supriyanto, E. Winarno, dan A. P. Utomo
}

\begin{abstract}
Program pengentasan kemiskinan merupakan prioritas bagi pemerintah daerah Kabupaten Banjarnegara yang harus ditangani. Penelitan ini bermaksud merancang bangun sebuah sistem informasi yang mengolah data penduduk yang dapat diolah menjadi sebuah informasi kemiskinan yang dapat diakses melalui web dengan menggunakan standar indikator kemiskinan menurut BPS. Metode yang digunakan dalam penelitian ini adalah dengan cara action research dan model pengembangan sistem informasi adalah secara terstruktur menggunakan waterfall. Hasil dari penelitian ini adalah dapat menyajikan informasi yang dapat menetukan kriteria kemiskinan dengan model singgle-criteria maupun multiple-criteria sesuai kebutuhan indikator kemiskinan yang ditentukan hingga pada tingkat desa, serta memberikan informasi tentang jenis-jenis bantuan yang telah diberikan pada setiap penduduk berdasarkan nama dan alamat (by name by address). Hasil selanjutnya adalah dapat dijadikan sebagai dasar pemetaan digital (Sistem Informasi Geografis/SIG) untuk menentukan kantong kemiskinan di suatu daerah, dengan memberikan pewarnaan yang menjadi indikator tingkat kemiskinan.
\end{abstract}

Kata Kunci : kemiskinan, sistem informasi, penduduk, indikator BPS, GIS.

\section{PENDAHULUAN}

1.1 Latar Belakang

Dalam rangka percepatan penanggulang kemiskinan diperlukan upaya penajaman yang meliputi penetapan sasaran, perancangan dan keterpaduan program, monitoring dan evaluasi, serta efektifitas anggaran, perlu dilakukan penguatan kelembagaan secara nasional guna menanggulangi kemiskinan (PP-RI No. 15, 2010) [1]

Aji Supriyanto, Fakultas Teknologi Informasi, Universitas Stikubank Semarang.

Edy Winarno, Fakultas Teknologi Informasi, Universitas Stikubank Semarang.

Agus Prasetyo Utomo, Fakultas Teknologi Informasi, Universitas Stikubank Semarang.
Guna men-dukung program pengentasan kemiskinan di Kabupaten Banjarnegara perlu adanya dukungan data yang akurat guna kepentingan pemetaan untuk melakukan identifikasi, perencanaan, analisis, pengembangan, pengawasan, dan penyebaran secara visual tentang potensi geografis secara tematik di wilayah Kabupaten Banjarnegara.

Berdasarkan hasil analisis di lapangan, kendala yang dihadapi Kabupaten Banjernegara selama ini dalam rangka melakukan identifikasi pendataan kemiskinan adalah terbatasnya sarana dan prasarana dalam melakukan pendataan seperti terbatasnya sarana atau perangkat pendataan yang efektif, tidak adanya database yang mudah di-update, tidak adanya data visual yang memudahkan dalam melihat, mengolah dan merubah data serta memberikan informasi yang berkaitan dengan dukungan dalam pemetaan data kemiskinan. Sehingga menjadikan proses pengolahan dan pengambilan keputusan yang berhubungan dengan dukungan pengentasan kemiskinan menjadi lebih sulit dan sering mengalami keterlambatan dan kekurang akuratan. Selain itu publik, baik masyarakat umum dan masyarakat yang berpotensi melakukan investasi juga belum dapat mendapatkan akses informasi yang cukup mudah dan cepat untuk mengakses potensi geografis Kabupaten Banjarnegara.

Di lain sisi setiap kelurahan atau desa telah memiliki data monografi, demografi, dan topografi yang merupakan data administrasi desa yang dapat menyajikan informasi keadaan daerah setempat secara lengkap [2]. Begitu juga, teknologi informasi (komputer dan internet) telah merambah ke pelosok daerah hingga ke desadesa, yang mestinya dapat dimanfaatkan secara maksimal untuk dapat mempermudah pengolahan data, penyajian informasi dan akses informasi secara on-line tentang segala potensi yang ada di masing-masing desa tersebut [3].

Guna memudahkan proses pembangunan Sistem Informasi Geografi (SIG) Data Kemiskinan diper-lukan suatu sistem pengolahan yang efektif dan efisien terhadap data-data yang ada [4]. Data kemiskinan di Kabupaten 
Banjarnegara yang tersusun nantinya merupakan sebuah sistem informasi berbasis peta geografis dimana informasi-informasi ditampilkan dalam layer-layer tematik tertentu. Sehingga untuk publikasi dan analisis data kemiskinan akan dengan mudah dilihat secara visual lewat tematik infomasi. Sistem Informasi Geografi Data kemiskinan di Kabupaten Banjarnegara diharapkan dapat dimanfaatkan berbagai pihak baik pemerintah maupun non-pemerintah, untuk dipergunakan dalam melakukan intervensi perencanaan program/kegiatan terkait masalah pengentasan kemiskinan di Kabupaten Banjarnegara.

\subsection{Tujuan Khusus dan Urgensi Penelitian}

1.2.1 Tujuan Khusus

Tujuan khusus penelitian ini adalah :

a. Tahun ke-1 :

1. Melakukan analisis data administrasi kependudukan yang dapat dijadikan sebagai indikator penentuan warga prasejahtera (miskin) dan sejahtera di Kabupaten Banjarnegara.

2. Mendesain database, interface input-output, dan informasi berkaitan dengan keadaan wilayah dan potensi, dan kondisi sosioekonomi penduduk, yang dapat dijadikan indikator kriteria kemiskinan.

3. Membuat perangkat lunak (software) berbasis web untuk mengolah data yang menjadi indikator kemiskinan serta dapat menyajikan informasi yang cepat dan realtime, akurat, transparan dan akuntabel yang dapat diakses secara on-line melalui internet, tentang kondisi sosial ekonomi penduduk berdasarkan nama dan alamat (by name \& by address).

b. Tahun ke-2 :

1. Membuat perangkat lunak peta on-line (Sistem Informasi Geografis/SIG) yang dapat menerima data dari database server yang memuat data indikator kemiskinan, dan menyajikan informasi dalam bentuk spasial tematik yang dapat dijadikan dasar pengambilan keputusan untuk penentuan prioritas pemberian bantuan baik oleh pemerintah Kabupaten Banjarnegara atau lembaga donor lainnya.

2. Membuat sistem yang dapat dijadikan acuan dasar yang sama bagi Tim Koordinasi Penanggulangan Kemiskinan Daerah (TKPKD) dalam mengelola database kemiskinan di daerah Kabupaten Banjarnegara.

\subsubsection{Urgensi Penelitian}

Informasi yang bernilai adalah informasi yang dapat disajikan secara akurat dan real-time, tepat waktu, transparan dan dapat dipertanggungjawabkan. Pengambilan data yang berkaitan dengan kondisi sosial ekonomi penduduk dan keadaan wilayah adalah sangat penting sebagai dasar untuk pengolahan menjadi bentuk yang lebih berguna dalam memberikan informasi yang berkaitan dengan kemiskinan. Sehingga penyajian informasinya secara cepat, tepat, realtime, transparan, dan mudah digunakan sangat diperlukan agar memiliki nilai atau fungsi yang tepat untuk membantu dalam pengambilan keputusan dalam pembangunan wilayah, dan pemerataan dalam penyediaan bantuan masyarakat miskin.

Kondisi yang ada saat ini bahwa pemerintah daerah Kabupaten Banjarnegara belum memiliki data dan informasi yang cukup yang dapat dijadikan dasar untuk penentuan pengolahan dan penyajian informasi tentang kemiskinan. Sehingga Tim Koordinasi Penanggulangan Kemiskianan Daerah (TKPKD) yang terdiri dari berbagai macam Satuan Kerja Pemerintah Daerah (SKPD) juga tidak memiliki acuan yang baku tentang data penduduk miskin. Akibat yang terjadi akurasi pendataan penduduk miskin masih belum dapat ditentukan secara pasti dengan hitungan yang sama karena menggunakan indikator kemiskinan yang berbeda. Hal ini tentunya masyarakat menjadi pihak yang sangat dirugikan karena pada akhirnya perhatian pemerintah pada masyarakat miskin tidak merata yang dalam hal ini proses pemberian bantuan kepada masyarakat miskin tidak dapat diidentifikasi dengan benar. Bantuan yang menumpuk atau berulang pada sekelompok masyarakat Rumah Tangga Miskin (RTM) masih sering terjadi. Di lain sisi ada sekelompok masyarakat RTM yang sama sekali belum pernah mendapatkan bantuan.

Penelitan yang akan dilakukan ini sangat bermanfaat guna mengatasi dan menyempurnakan kendala-kendala yang terjadi sehingga memiliki keunggulan-keunggulan sebagai berikut :

1. Terbangunnya sebuah sistem informasi database server kemiskinan berbasis web yang dapat digunakan sebagai acuan atau kesepakatan bersama oleh TKPKD Kabupaten Banjarnegara tentang pendataan kemiskinan.

2. TKPKD Kabupaten Banjarnegara dapat mengisi, mengolah, menyajikan tentang data kemiskinan dengan indikator yang sama. Dan 
stagholder dapat memonitoring tentang jenisjenis bantuan yang pernah diberikan oleh pemerintah daerah setempat atau oleh pihak lain dan yang telah diterima oleh masyarakat Rumah Tangga Miskin (RTM) di Kabupaten Banjarnegara secara transparan dan akuntabel.

3. Database sistem administrasi data kemiskinan dapat dijadikan dasar pembangunan Sistem Informasi Geografis (SIG) pemetaan daerah kemiskinan (prasejahtera) yang menjadi prioritas untuk segera dilakukan penanggulangan kemiskinan, sehingga informasi ini sekaligus sebagai alat bantu pengambil keputusan eksekutif dalam rangka percepatan pengentasan kemiskinan.

4. Terbangunnya Sistem Informasi Geografis (SIG) yang menghasilkan informasi spasial tematik yang berkaitan dengan masalah sebaran penduduk dan masalah sosial ekonominya termasuk indikator golongan penduduk yang miskin (prasejahtera).

5. Terbangunnya arsitektur informasi berbasis web dan SIG, sebagai pedoman implementasi Sistem Informasi Desa (SIMDES) di Kabupaten Banjarnegara. Pada peta ini akan dapat dengan cepat untuk dicari nama Rumah Tangga Miskin (RTM), pendapatan rumah tangga , pekerjaan, jumlah keluarga dan posisi rumah tinggal yang bersangkutan dengan tingkat ketepatan sesuai dengan posisi derajat spasial.

\section{STUDI PUSTAKA}

\subsection{State of The Art}

Sistem informasi merupakan sebuah sistem berbasis komputer yang dapat mengolah data untuk dapat disajikan menjadi bentuk yang lebih berarti dan bermanfaat bagi organisasi [5]. Dalam membangun sebuah sistem informasi dibutuhkan berbagai komponen seperti data dan basis data, software dan hardware komputer, prosedur, dan personal. Kesemua komponen tersebut harus saling mendukung, terintegrasi, dan saling berinteraksi dalam melakukan aktifitasnya. Pembangunan database adalah sangat penting terhadap keberhasilan informasi yang akan dihasilkan, kelengkapan dan kebenaran data yang diperoleh akan berpengaruh terhadap terbangunnya sistem database [5].

Dalam studi kependudukan dilakukan bersama mahasiswa menghasilkan database kependudukan dan informasi tentang keadaan demografi wilayah desa. Informasinya berupa kelahiran, kematian, perpindahan (urban), dan informasi-informasi yang mendukung terhadap status identitas penduduk seperti kartu keluarga, akte kelahiran, dan statistika kependudukan [3]. Dalam studi yang lain dilakukan yaitu dinamika monografi dan inventarisasi desa telah dilakukan menghasilkan database monografi dan data inventaris desa yang dapat menyajikan informasi mengenai keadaan dan potensi di wilayah desa/kelurahan. Informasi yang disajikan dapat menggambarkan antara lain tentang batas-batas yang dimiliki, keadaan geografis setempat, jumlah penduduk, mata pencaharian/pekerjaan, agama, jumlah rukun tetangga dan jumlah rukun warga, sarana jalan, tempat ibadah, sarana umum, dan sejenisnya yang setiap saat dapat dibuat laporannya sebagai arsip dan laporan kepada lembaga di atasnya yaitu kecamatan [6].

\subsection{Terminologi Kemiskinan}

Kemiskinan adalah kondisi dimana seseorang atau sekelompok masyarakat tidak mampu memenuhi hak-hak dasarnya untuk mempertahankan dan mengembangkan kehidupan yang bermartabat [1]. Hak-hak dasar antara lain (a) Terpenuhinya kebutuhan pangan, (b) kesehatan, pendidikan, pekerjaan, perumahan, pertanahan, sumber daya alam dan lingkungan hidup, (c) rasa aman dari perlakuan atau ancaman tindakan kekerasan, (d) hak untuk berpartisipasi dalam kehidupan sosial politik. Dalam konteks kemiskinan dapat ditentukan beberapa kriteria yaitu kemiskinan relatif, kemiskinan absolut, dan kemiskinan kultural.

Badan Pusat Statistik (BPS) dalam menghitung data kemiskinan menggunakan sumber data SUSENAS (Survei Sosial Ekonomi Nasional) [7]. Sebagai informasi tambahan, digunakan hasil survei SKPD (Survei Paket Komoditi Kebutuhan Dasar) yang digunakan untuk memperkirakan proporsi dari pengeluaran masing-masing komoditi pokok non- makanan. Sedangkan metode yang digunakan adalah Garis Kemiskinan Makanan (GKM) dan Garis Kemiskinan Non-Makanan (GKNM), sebagai berikut [7]:

$$
\mathrm{GK}=\mathrm{GKM}+\mathrm{GKNM}
$$

\subsection{Sistem Informasi Geografis (SIG)}

Sistem Informasi Geografis (SIG) adalah sebuah sistem informasi berbasis komputer yang digunakan untuk memproses data spasial (bereferensi keruangan). Dalam beberapa literatur menyebutkan bahwa SIG dipandang sebagai hasil dari perkawinan antara sistem komputer bidang 
kartografi dengan teknologi basis data (Darwis, 2008). Subsistem pengolahan data SIG terdiri dari beberapa subsistem yaitu data input, data output, data management, data manipulasi dan analisis yang secara visual dalam pemrosesan data input menjadi output.

\subsection{Road Map Penelitian}

Berdasarkan dari hasil-hasil penelitian yang dilakukan terdahulu, dan kegiatan yang akan dilakukan dalam penelitian ini dapat digambarkan menggunakan peta alur (road map) seperti Gambar 1 berikut ini:

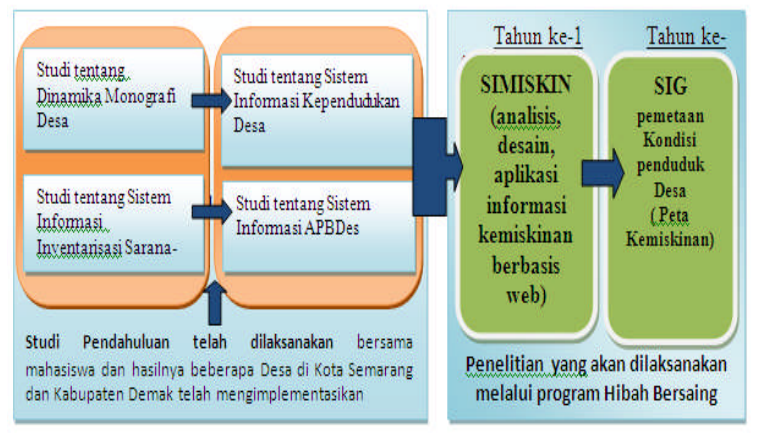

Gambar 1. Road map penelitian

Dari Gambar 1 di atas, maka bagan alir tahapan-tahapan penelitian yang dilakukan adalah seperti Gambar 2 berikut ini :

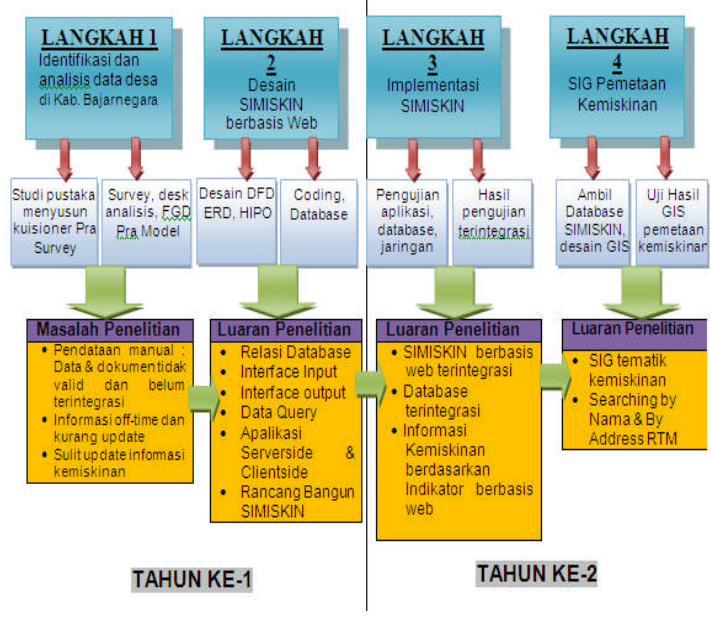

Gambar 2. Bagan alir penelitian SIG Data Kemiskinan

\section{METODE PENELITIAN}

Dalam penelitian ini akan dikembangkan sebuah perangkat lunak (software) yang dapat digunakan untuk mengolah data dan menyajikan informasi sesuai kebutuhan institusi yang dapat diakses melalui web/internet dan dalam bentuk visualisasi sistem informasi geografis dari data yang telah dimasukkan. Untuk itu penelitian ini menggunakan metode Action Research, dengan model pengembangan System Development Life Cycle (SDLC) teknik analisis dan desain terstruktur yang terdiri dari analisis sistem, desain sistem, implementasi dan pengujian sistem.

\section{PEMBAHASAN DAN HASIL}

\subsection{Tahap Analisis Sistem}

Analisis kebutuhan sistem berbasis komputer dftakukan terhadap komponen-komponen yang terlibat seperti perangkat lunak komputer (software), basisdata (database), dokumentasi, perangkat keras komputer (hardware), orang, dan prosedur (procedure). Teknik analisis terstruktur terhadap data dilakukan dengan menggunakan Data Flow Diagram (DFD), yaitu menganalisis keterkaitan entitas luar sistem terhadap prosesproses yang berlangsung terhadap internal sistem, yang dapat menghasilkan dokumen (arsip). Database terbentuk karena adanya sebuah relasi antar tabel. Gambaran DFD SIG Data Kemiskinan seperti Gambar 3 berikut:

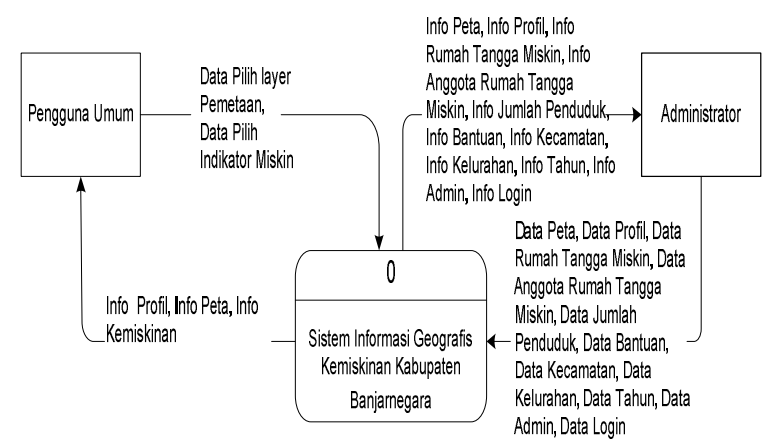

Gambar 3. Diagram Konteks SIG Data Kemiskinan

\subsection{Tahap Desain Sistem}

Tujuan dari desain sistem secara umum adalah untuk memberikan gambaran secara umum kepada user dan manajemen tentang sistem aplikasi baru yang dibuat.

a. Desain Tabel

Hasil dari analisis sistem yang ditemukan, selanjutnya dilakukan rancangan sistem yaitu merancang sebuah tabel-tabel yang merupakan hasil dari dokumen analisis terstruktur dengan DFD. Tabel-tabel tersebut nantinya akan dijadikan dasar dalam melakukan rancangan relasi antar tabel (Entity Relation Diagram/ERD) yang menjadi dasar terbentuknya sebuah database sistem informasi. Model ERD-nya dapat terlihat seperti Gambar 4 berikut ini: 


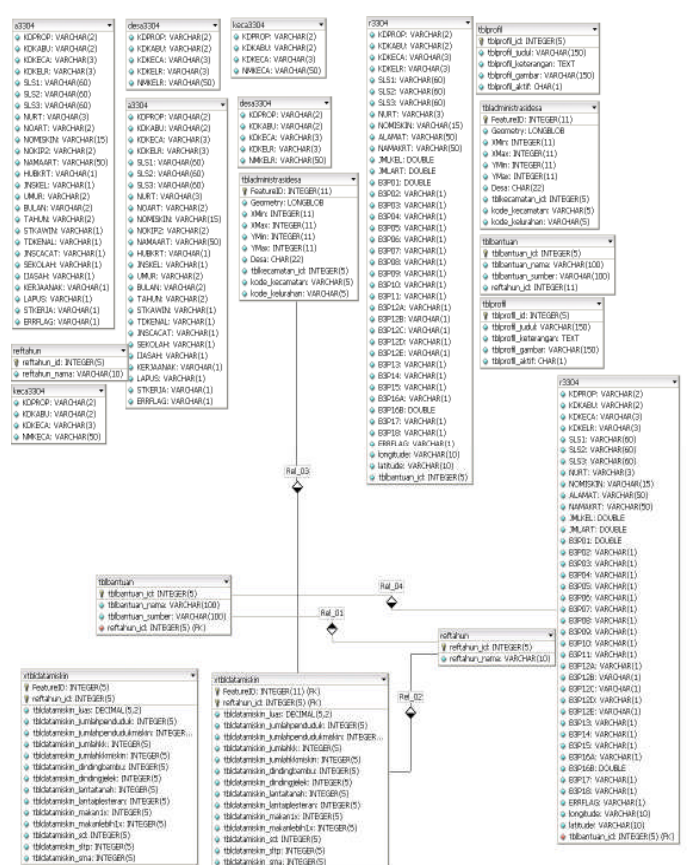

Gambar 4. Diagram Entity Relational

\section{b. Desain User Interface}

Desain User Interface (UI) adalah desain tampilan bagi para pengguna baik sebagai user biasa maupun administrator. Setiap pengguna sistem harus melalui tahap otentikasi sistem yaitu melalui login user atau login admin.

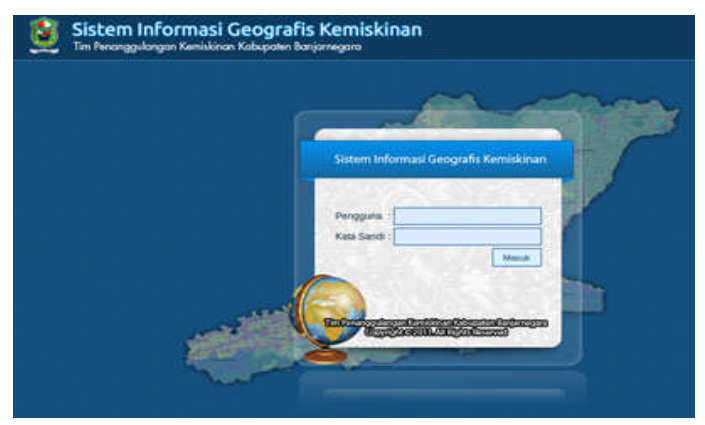

Gambar 5. Tampilan awal login

Sedangkan desain UI untuk penentuan criteria indikator kemiskinan dibuat dengan model multiple-criteria mengunakan properti cek bok pada aplikasi. Ini dimaksudkan agar pemilihan kriteria dapat dilakukan secara opsional dari satu kriteria, beberapa kriteria hingga semua kriteria sesuai dengan pilihan pengguna. Setiap melakukan pemilihan pada cek, akan ditampilkan keterangan cek bok tersebut yang menunjukkan indikator kriteria kemiskinan terpilih, seperti Gambar 6 berikut ini:

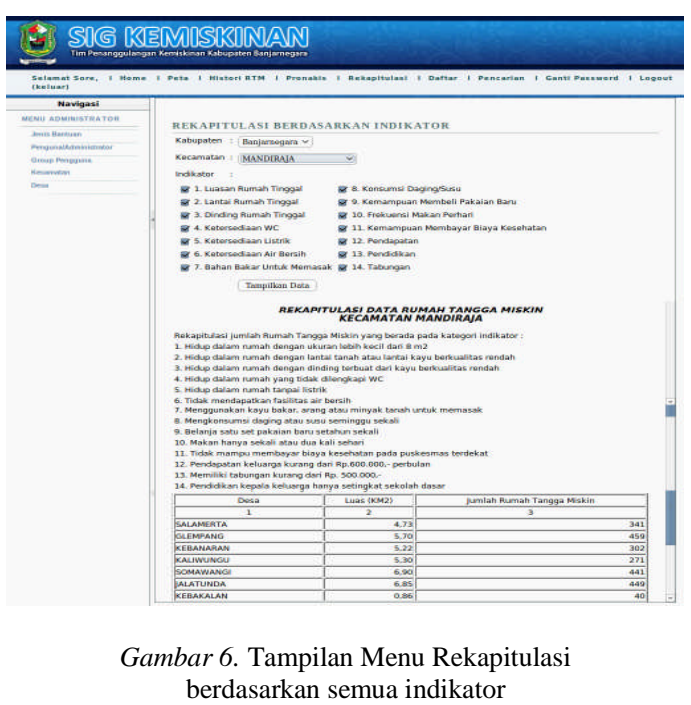

Desain UI juga dibuat untuk Program Penanggulangan Kemiskinan (PRONAKIS). Desain ini member informasi tentang warga miskin berdasarkan jenis bantuan yang diterima dan nilainya. Hal ini akan dapat membantu bagi TKPK (Tim Koordinasi Penanggulangan Kemiskinan) dalam menentukan siapa saja yang sudah mendapat bantuan dan siapa saja yang belum pada periode tertentu.

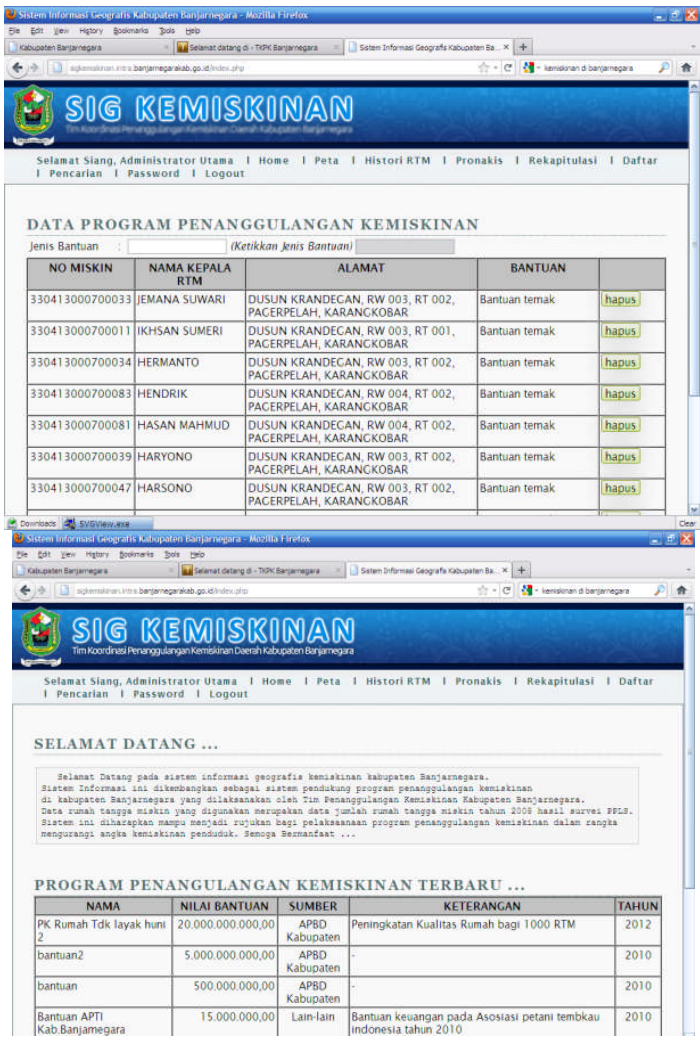

Gambar 7. UI Program Penanggulangan Kemiskinan 
Desain UI juga dilakukan dalam rangka membuat rekapitulasi jumlah rumah tangga miskin pada tiap-tiap kelurahan suatu kecamatan tertentu dengan memperlihatkan informasi nama desa, luas desa, dan jumlah rumah tangga miskin, seperti Gambar 8 berikut ini :

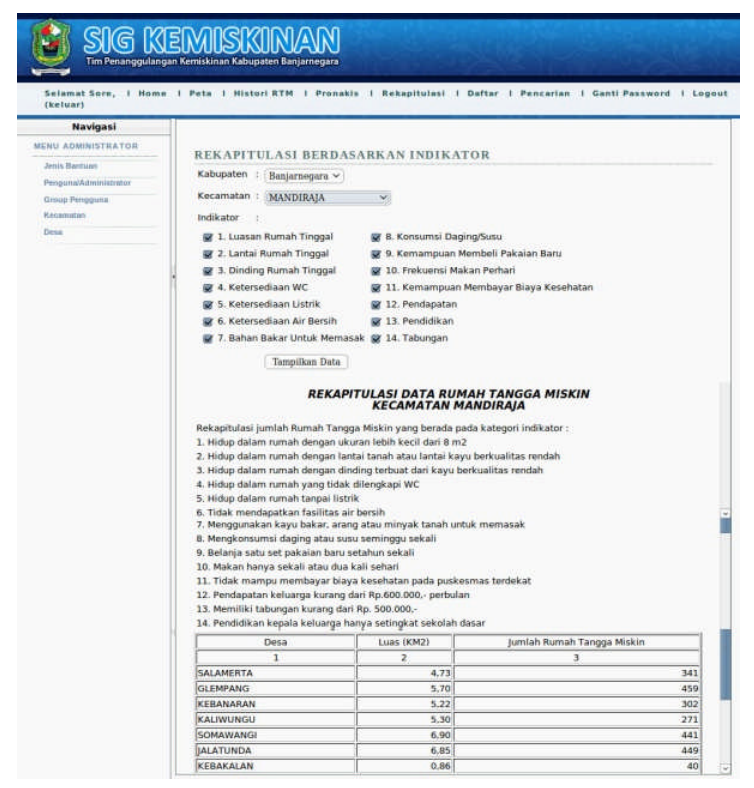

Gambar 8. UI Rekapitulasi Penduduk Miskin

\subsection{Implementasi, Pengujian dan Hasil}

Sistem Informasi Kemiskinan yang telah dirancang bangun dengan menggunakan tool, sebelum dilakukan implementasi di lapangan sebelumnya perlu dilakukan pengujian. Pengujian dilakukan dilakukan dengan model pengujian laboratorium dan pengujian lapangan. Pengujian laboratorium merupakan pengujian Sistem Informasi Kemiskinan pada skala laboratorium seperti pengujian secara localhost pada sistem yang dirancang dan pengujian pada jaringan lokal di laboratorium komputer.

Pengujian lapangan sangat penting dilakukan karena akan menunjukkan bahwa sistem tersebut nantinya benar-benar dapat dimplementasikan. Pada prinsipnya pengujian laboratorium dengan pengujian lapangan hampir sama, hanya pada pengujian lapangan sistem informasi kemiskinan diimplemen-tasikan dengan jaringan lokal menggunakan wireless yang diakses oleh Tim Koordinasi Penanggulangan Kemiskinan (TKPK) yang merupakan calon pengguna sistem sesungguhnya.

Dari hasil rancangan sistem, pengujian sistem pertama kali dilakukan untuk menguji tentang otentikasi login user baik secara administrator maupun operator. Fungsi otentikasi ini sangat penting untuk menentukan kewenangan seorang user dalam melakukan pengolahan data, hasilnya dapat digambarkan seperti Gambar 9 berikut ini :

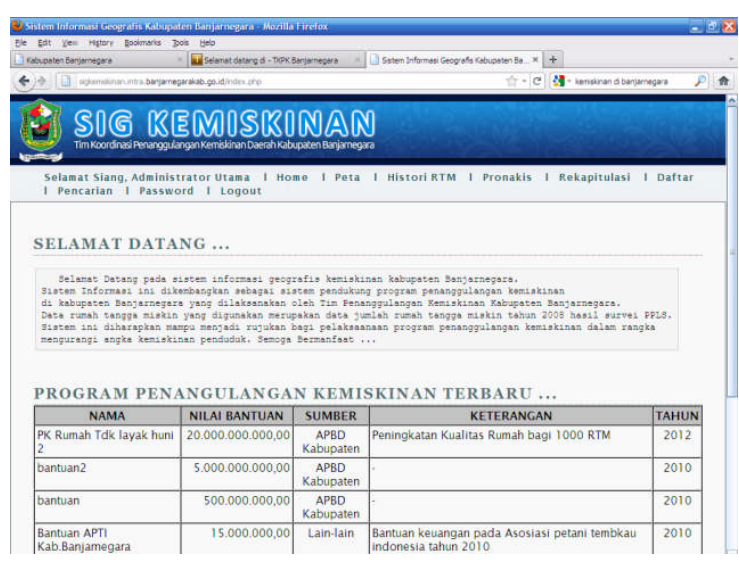

Gambar 9. Halaman awal (Home) pada Login Administrator

Pada Gambar 9 tersebut telah terlihat bahwa pada halaman awal administrator terdapat menumenu sebagai berikut :

- Home, berfungsi menampilkan halaman awal SIM/SIG Kemiskinan

- Peta, berfungsi menampilkan visualisasi peta daerah miskin hingga tingkat desa/kelurahan

- Histori RTM, melakukan pencarian data Rumah Tangga Miskin (RTM) berdasarkan NoMiskin, dan nama kepala RTM yang hasilnya akan menampilkan daftar anggota RTM beserta histori-nya per anggota RTM

- Pronakis, berfungsi untuk mendata RTM yang telah atau belum mendapatkan bantuan kemiskinan pada periode tertentu.

- Rekapitulasi, berfungsi untuk menentukan rekapitulasi hasil RTM pada kecamatan dan kelurahan/desa tertentu dengan indikator kemiskinan tertentu.

- Daftar Pencarian, berfungsi untuk mencari data RTM berdasarkan tanda pengenalnya, jenis kecacatan, partisipasi sekolah, ijazah, jenis pekerjaan, lapangan usaha, kedudukan dalam jenis pekerjaan/usaha.

- Password, berfungsi untuk administrator apabila melakukan penggantian atau update password user

- Logout, berfungsi untuk keluar dari login administrator atau operator.

Pada topik penelitian ini yang harus diselesaikan pada tahun pertama adalah semua topik di atas kecuali pada menu peta yang menjadi topik pada penelitian hibah pada tahun kedua. Pada Gambar 10 berikut ini ditampilkan contoh hasil rekapitulasi berdasarkan indikator kemiskinan. 


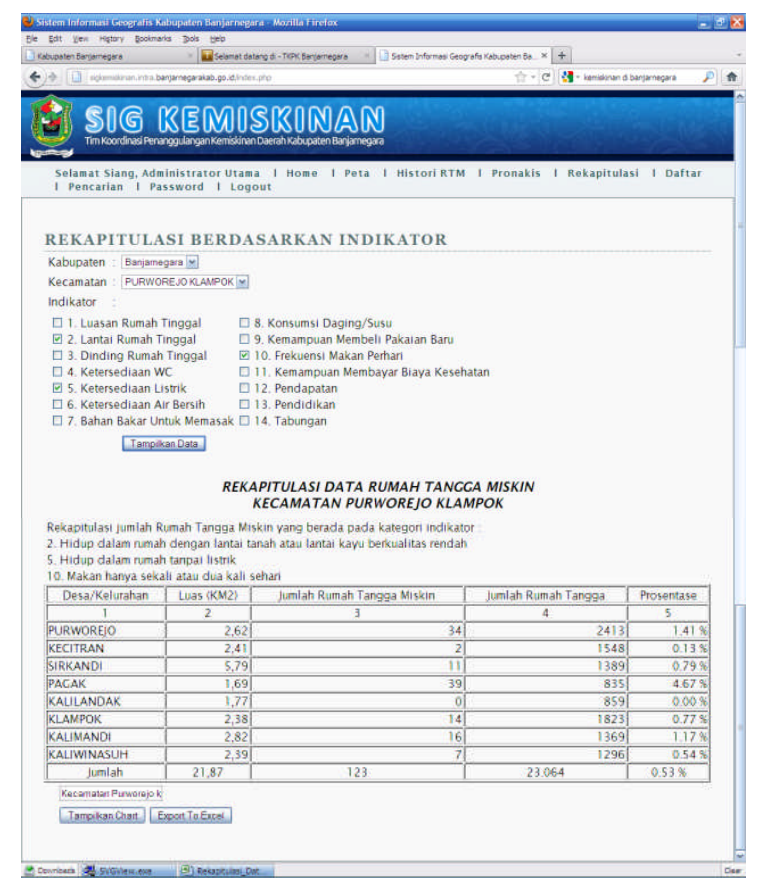

Gambar 10. Tampilan Rekapitulasi berdasarkan Indikator Kemiskinan

Sedangkan contoh tampilan statistik tentang jumlah Rumah Tangga Miskin (RTM) dapat diperlihatkan pada Gambar 11 berikut ini.

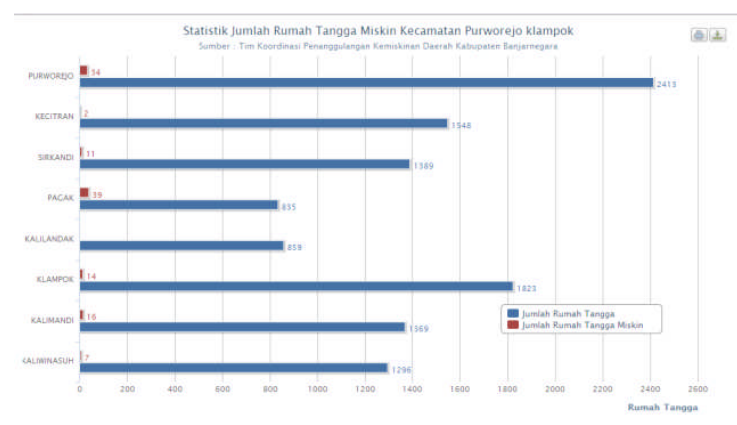

Gambar 11. Contoh tampilan Statistika Jumlah RTM pada Kecamatan Purworejo Klampok

\section{KESIMPULAN}

Rancang bangun Sistem Informasi Manajemen (SIM) Kemiskinan ini dapat menentukan data kemiskinan berdasarkan indikator yang diberlakukan oleh BPS. Informasi yang dihasilkan pada SIM Kemiskinan dapat diketahui RTM berdasarkan pada indikator tertentu baik secara single-criteria maupun multicriteria, dan dijadikan acuan oleh TKPK Pemerintah Daerah Kabupaten Banjarnegara untuk menyusun strategi program penanggulangan kemiskinan (PRONAKIS).
Hasil dari SIM Kemiskinan tersebut yang merupakan hasil penelitian tahun ke-1 perlu segera dapat diimplementasikan di Kabupaten Banjarnegara. Dan untuk penyempurnaan penelitian tersebut perlu dilanjutkan penelitian tahun kedua yang akan membahas tentang pemetaan angka kemiskinan menggunakan visualisasi peta geografis (SIG) yang mudah dipahami dan dibaca oleh pengguna sistem.

\section{DAFTAR PUSTAKA}

[1] Peraturan Pemerintah Republik Indonesia (PP-RI) No. 15, 2010, Percepatan Penanggulangan Kemiskinan, www.bappenas.go.id, diakses tang-gal 10 juli 2011.

[2] Aji Supriyanto, Rio Aditya D., 2009, Sistem Informasi Dinamika Monografi Kelurahan Mranggen Kecamatan Mranggen Kabupaten Demak, Laporan Penelitian, UNISBANK Semarang.

[3] Aji Supriyanto, Fajar Bungsu, 2010, Sistem Informasi Administrasi Kependudukan kelurahan Mranggen Kecamatan Mranggen Kabupaten Demak, Laporan Penelitian, UNISBANK Semarang.

[4] E. Budiyanto, 2003, Sistem Informasi Geografis Menggunakan Arc View GIS, Andi, Yogyakarta.

[5] Aji Supriyanto, 2005, Pengantar Teknologi Informasi, Salemba Informatika, Jakarta.

[6] Idi Jang Cik, 2005, Sistem Pengolahan Data Spasial Tingkat Kesejahteraan Penduduk DIY dengan MapInfo, Laporan Penelitian, Universitas PGRI Yogyakarta.

[7] BPS, 2008, Data Penduduk Miskin di Indonesia Sampai Dengan Maret 2008, www.bps.go.id, diakses tanggal 20 juli 2011. 